\title{
Cadmium and zinc uptake, growth, and primary production in Coscinodiscus granii cultures containing low levels of cells and dissolved organic carbon
}

\author{
U. Rabsch ${ }^{1} \&$ M. Elbrächter ${ }^{2}$ \\ ${ }^{1}$ Institut für Meereskunde; D-2300 Kiel, Federal Republic of Germany, \\ and \\ ${ }^{2}$ Biologische Anstalt Helgoland (Litoralstation); \\ D-2282 List/Sylt, Federal Republic of Germany
}

\begin{abstract}
Coscinodiscus granii Gough was cultivated at low cell densities in aged Atlantic sea water containing very little dissolved organic carbon; the water was enriched with low levels of nutrients but no chelators were added. Cadmium additions provided final concentrations of 0.1 to $26.5 \mu \mathrm{g} \mathrm{Cd} \mathrm{^{-1 }}$, zinc being kept constant at a level of $38 \mu \mathrm{g} \mathrm{Zn} \mathrm{l}^{-1}$. Carrier-free ${ }^{109} \mathrm{Cd}$ and ${ }^{65} \mathrm{Zn}$ were used as tracers for the two metals. Growth in terms of cell numbers and primary productivity capacity, using the ${ }^{14} \mathrm{C}$ uptake rate, was followed during the exponential growth phase for the first 5 days of the experiment and then for a further 3 days during the stationary phase. On each day, the metal contents of the cells were determined. Cadmium concentrations of $20 \mu \mathrm{g} \mathrm{Cd} \mathrm{l}^{-1}$ and more resulted in growth inhibition whereas $17.5 \mu \mathrm{g} \mathrm{Cd} \mathrm{l^{-1 }}$ reduced the growth only slightly. The physiological state of the cells influenced the heavy-metal uptake per cell at sublethal Cd levels. Dead cells had a higher heavy-metal concentration than living cells. Microscopical observations revealed that cells just about to divide were less sensitive to a given toxic heavy-metal concentration than cells which had recently divided. This might have been due to different surface/volume ratios.
\end{abstract}

\section{INTRODUCTION}

Upwelling water containing a low concentration of organic carbon usually needs a certain time before plankton will grow in it (Barber \& Ryther, 1969). It is also known that upwelling water has an enhanced content of heavy metals (Riley \& Taylor, 1972). Thus the initial depression of primary production in such water may be due to this higher metal content. Addition of chelator or homogenised plankton has been shown to enhance the primary production capacity of newly upwelled water (Barber \& Ryther, 1969; Barber et al., 1971) possibly due to the detoxification of the metals (Steeman Nielsen \& Wium Anderson, 1971).

Heavy metals are known to be toxic to phytoplankton even at low levels (Davies, 1978). As the same author pointed out, the toxicity is dependent on several external factors. In cultures, one of these is the composition of the medium. The presence of chelators as well as the concentrations of the nutrients may have an effect on the toxicity of the metals. Chelators can reduce the activity of metals. The calculations of Spencer 
(1958), for instance, indicated that at EDTA concentrations of $10^{-5}$ molar, the order of magnitude present, for example, in the f/2 culture medium (MacLachlan, 1973), metals like copper and zinc are present largely in chelated form. As suggested by Davies (1978), high concentrations of nutrients may have an influence on the metal effects and their toxicity. High cell numbers may have the same effect, as it is the quantity of metal taken up by the cells which ultimately determines its effect upon growth. In dense cultures, more metal is required to produce a given cellular burden (Davies, 1978). This effect could be enhanced by the release of organic substances by the cells which detoxify the medium by chelation (Steeman Nielsen \& Wium Anderson, 1971; Hellebust, 1974).

To take this into consideration in the present experiment, aged sea water with a low dissolved organic carbon content was used. Cell concentrations were kept at about the level of natural populations (see Table 1).

The effect of a constant heavy metal concentration may be different during the course of the cell-division cycle. Therefore, a method was developed to follow not only the number of living and dead cells but also the different morphological stages during the logarithmic growth phase and the stationary phase. Culture conditions were arranged to include both these phases. As shown by the results of the following experiment the physiological state of the cells had indeed an influence on the heavy metal uptake rate. This results in high variability of the experimental data. A detailed study on the influence of heavy metals and their uptake rates during the cell-division cycle of a synchronised culture will follow. Here we present the method and first results.

\section{MATERIAL AND METHODS}

\section{Culture technique}

Aged Atlantic sea water with a low dissolved organic carbon (DOC) content of 0.25 mg C $1^{-1}$, an amino-acid content of $0.14 \mu \mathrm{mol}$ glycine equivalents $\mathrm{l}^{-1}$ (Dawson \& Liebezeit, 1980) and respective cadmium and zinc contents of $0.014 \mu \mathrm{g} \mathrm{l}^{-1}$ and $4.25 \mu \mathrm{g} \mathrm{l}^{-1}$ was prepared for the experiments in the following way: the water was enriched with nutrients (Table 1), sterilized by filtration through a $0.2-\mu \mathrm{m}$ pore size membrane filter directly into 2-l steam-sterilized, quartz glass bottles already containing about $3 \mu \mathrm{Ci}$ ${ }^{109} \mathrm{Cd}$ and $10 \mu \mathrm{Ci}{ }^{65} \mathrm{Zn}$, both carrier-free, and cadmium concentrations ranging between 0 and $26.5 \mu \mathrm{g} \mathrm{l}^{-1}$ (Table 1). About 1.71 of water was added to each bottle, duplicate bottles being set up for each concentration. During the preparations, the zinc content of the medium increased to $38 \mu \mathrm{g} 1^{-1}$ due to the nutrient additions. After preparation, the samples were kept for 4 weeks at $18{ }^{\circ} \mathrm{C}$ to allow equilibration between the radioactive tracers and the metals naturally present. During this time the radioactivity remained constant, indicating that no adsorption had occurred and there was no evidence of bacterial growth. The low levels of particulate metals present $(0.08 \%$ of total for Cd and $0.26 \%$ for $\mathrm{Zn}$ ) have been used to correct the data. Before inoculation, $0.7 \mu \mathrm{g} \mathrm{l^{-1 }}$ cobalamin was added to the medium.

The 2-1 quartz culture vessels were closed with a teflon stopper which had 3 nozzles outside and 2 quartz tubes inside for aeration, sampling, and ventilation. The bottles were kept at $18^{\circ} \mathrm{C}$ in an incubator (Rubarth \& Co) and were illuminated by Philips TLW 33 fluorescence tubes while rotating on a two-level plexiglass turntable. The average 


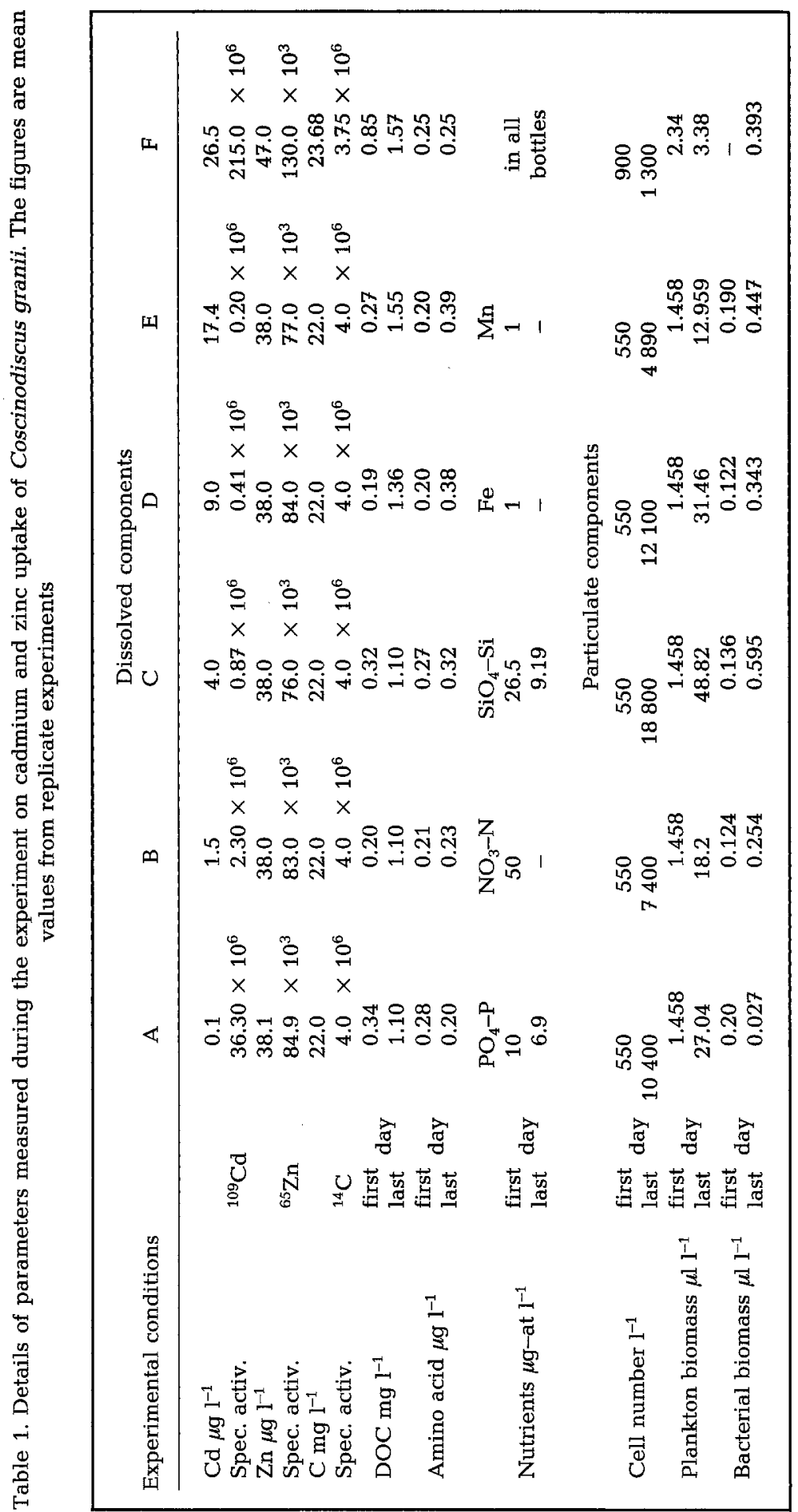


light density was $7.4 \mathrm{~W} \mathrm{~m}^{-2}$ with a light-dark cycle of LD 12:12. For primary production measurements in $50-\mathrm{ml}$ sovirel bottles, a Gargas incubator was used at $18^{\circ} \mathrm{C}, 14 \mathrm{~W} \mathrm{~m}^{-2}$ light and $4 \mathrm{~h}$ incubation time. Cell counts were made on membrane filters under a dissecting microscope (Wild M 5), using darkfield illumination.

Coscinodiscus granii Gough was isolated on 8 September 1977 from plankton samples taken off List/Sylt, German Bight, North Sea, by Dr. Drebes, List/Sylt. The strain is of the so-called "major-form" (Drebes, 1974). During the experiments, the cells had a diameter of 180 to $200 \mu \mathrm{m}$, the mean being $191 \mu \mathrm{m}$. The cell surface was calculated to be about $5.5 \times 10^{4} \mu \mathrm{m}^{2}$ and its volume about $2.63 \times 10^{6} \mu \mathrm{m}^{3}$, the latter confirmed by Coulter Counter measurements. Cells shortly before cell division had approximately twice the volume but the surface was only slightly enlarged before the cells separated completely. Stock cultures were cultivated for 3 weeks with 4 serial tranfers in the same medium in order to allow physiological adaptation to the test medium. For the experiments, the cell density at the beginning was approximately 600 cells $1^{-1}$.

The sampling was done every day, two hours after illumination started, using 20- to 50-ml medical syringes. From each bottle, 2 to 3 samples were taken for primary productivity measurements, a sample to control the radioactivity in the water, and, every second day, samples for bacteria counting and biomass determination. Further samples were used to determine the following chemical parameters: DOC, amino-acid content, nutrients $\left(\mathrm{NO}_{3}-\mathrm{N}, \mathrm{SiO}_{4}-\mathrm{Si}, \mathrm{PO}_{4}-\mathrm{P}\right)$, alkalinity and the specific activities of ${ }^{109} \mathrm{Cd}$ and ${ }^{65} \mathrm{Zn}$ at the beginning and the end of the experiment. The trace-metal determination was carried out in a PAR Mod. 174 polarographic analyzer by inverse stripping voltammetry. To analyze the metal content of the particulate material, water was filtered through 2 Satorius $0.45-\mu \mathrm{m}$ pore size $25-\mathrm{mm}$ diameter membrane filters, the same used as for the productivity measurements. Before the filters were analyzed, plankton was counted on each of them.

\section{Calculation}

Measurements of radioactivity were made in a three-channel liquid scintillation counter (BF 5000 Labor Prof. Berthold) and a two-channel gamma sample changer (BF $5000 \mathrm{G}$ Labor Prof. Berthold), the latter being equipped with a $2 \frac{1}{2}{ }^{\prime \prime} \mathrm{NaI}(\mathrm{Li})$ well-type crystal. The samples were dissolved in $6 \mathrm{ml}$ Instagel II (Packard) contained in 8-ml glass vials. The glass vials were counted in both instruments. The efficiency in the gamma sample changer was $31 \%$ for ${ }^{109} \mathrm{Cd}$ and $42 \%$ for ${ }^{65} \mathrm{Zn}$. In the liquid scintillation counter, it was $178 \%$ for ${ }^{109} \mathrm{Cd}$ and $187 \%$ for ${ }^{65} \mathrm{Zn}$ and $93 \%$ for ${ }^{14} \mathrm{C}$ measuring with open channels. Since all three nuclides were measured together in the samples, the liquid scintillation counter was used in the three-channel mode. In the highest energy channel, a small fraction of ${ }^{65} \mathrm{Zn}$ was measured which was used to correct the middle channel for its small zinc component. In this channel, $85 \%$ of the ${ }^{109} \mathrm{Cd}$ and $84 \%$ of ${ }^{14} \mathrm{C}$ were measured. In the low energy channel, the main ${ }^{65} \mathrm{Zn}$ activity was measured which had to be corrected for $5 \%$ of the activity from the ${ }^{109} \mathrm{Cd}$ and $6 \%$ of that of ${ }^{14} \mathrm{C}$. The quench due to the water and to the chlorophyll was measured by the ${ }^{137} \mathrm{Cs}$ external standard channel ratio, and in relation to this, different spill-over factors were used. The ${ }^{14} \mathrm{C}$ activity was calculated by using the ${ }^{65} \mathrm{Zn}$ and ${ }^{109} \mathrm{Cd}$ measurements from the gamma counter. In the range of 4000 counts $\mathrm{min}^{-1}$ and counting time $10 \mathrm{~min}$, the 2 sigma standard deviation for each nuclide was within $\pm 2 \%$. 
After calculating the radioactivity for the isotopes in the filter and water samples, the upper filter samples were corrected for the radioactivity of the subfilters which were used to measure the absorbed water. The counting background was subtracted in the counting programme. Then, with the help of the determined specific activity of each sample, the metal and carbon contents were calculated. By using the related cell numbers for each filter, the contents per million cells could be calculated. The mean values of the results were plotted against cell numbers in the cultures to provide comparable points for cell density. Mean doubling times with confidence limits $(95 \%$ level) were calculated during the logarithmic growth phase.

\section{RESULTS}

\section{Growth of Coscinodiscus granii}

Culture conditions of Coscinodiscus granii were chosen so that logarithmic growth occurred at least during the first 5 days of the experiment before the stationary phase began. During the logarithmic growth phase, the mean doubling time of the controls was equal to that of the stock cultures cultivated in Guillards f/2 medium (MacLachlan, 1973), being about 26 hours. The presence of cadmium up to a concentration of $9.1 \mu \mathrm{g} \mathrm{Cd}$ $1^{-1}$ had no influence on the mean doubling time of this species (Tables 1,2$)$. No growth occurred in cultures containing $20 \mu \mathrm{g} \mathrm{Cd}^{-1}$ or more. In conclusion, we can state that a

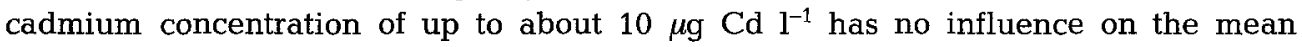
doubling time of Coscinodiscus granii under the conditions investigated, that a concentration of $20 \mu \mathrm{g} \mathrm{Cd}^{-1}$ and more prevented growth totally whereas a concentration of about $17.5 \mu \mathrm{g} \mathrm{Cd} \mathrm{l}^{-1}$ influenced the mean doubling time slightly.

Direct microscopic observations of cells inoculated into a medium with a $\mathrm{Cd}$ concentration of $25 \mu \mathrm{g} \mathrm{l^{-1 }}$ showed that cells had plasmolysed in the course of two minutes. After $4 \mathrm{~min}$, cytoplasm protruded from the wall of some cells and formed spheres of different diameters. These spheres were built up from a hyaline thin layer of cytoplasm surrounding a large vacuole. At the pole where the cytoplasm had protruded from the cell wall, some chromatophores were present in most cases. Some of these spheres detached from the cells and persisted for days in the culture vessels. This

Table 2. Coscinodiscus granii. Mean doubling time plus confidence limits (95\% level) in relation to different cadmium concentrations of the medium

\begin{tabular}{|cc|}
\hline $\begin{array}{c}\text { Cd concentration } \\
\left(\mu \mathrm{g} \mathrm{l}^{-1}\right)\end{array}$ & $\begin{array}{c}\text { Mean doubling time } \\
(\mathrm{h})\end{array}$ \\
\hline 0.1 & $24.8 \leqq 29.2 \leqq 35.4$ \\
1.5 & $21.8 \leqq 27.6 \leqq 37.6$ \\
4.0 & $17.0 \leqq 21.9 \leqq 30.6$ \\
9.0 & $20.9 \leqq 27.0 \leqq 37.9$ \\
17.5 & $29.6 \leqq 52.1 \leqq 220.8$ \\
20.0 & no growth \\
26.5 & no growth \\
50.0 & no growth \\
\hline
\end{tabular}


behaviour is typical for cells not directly involved in cell division. Elongated cells shortly before division or cells in which cytoplasmic division had finished but where the daughter cells were still connected by the girdle (Drebes, 1974: Fig. 26a) showed plasmolysis but, in most cases, no cytoplasmic extrusions. The cytoplasm of some of these cells deplasmolysed, looked like untreated cells after 1 to 2 days, but cell division did not start again even after 6 days. When cells were inoculated into a medium

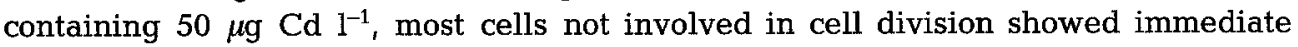
plasmolysis, some cells undergoing complete lysis after 2 to 4 min. Daughter cells which were still connected showed plasmolysis and cytoplasm protrusions as described for

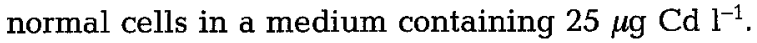

\section{Metal and carbon uptake}

During the experiment, the metal concentration of the water in the different bottles remained constant for cadmium and decreased by about $5 \%$ in the case of zinc. As shown in Figures 1 to 4, the cadmium uptake of Coscinodiscus granii depended on the concentration of the metal in the water. It also tended to follow the carbon uptake, the more so at the higher cadmium concentrations. Up to $1.4 \mu \mathrm{g} \mathrm{Cd} \mathrm{I}^{-1}$, the concentration in

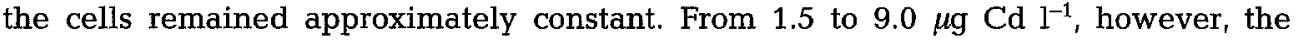
cadmium concentration in the cells remained at about the same level during logarithmic growth but increased at the end of this growth phase. In the bottles containing higher levels of cadmium solution, the uptake increased from the very beginning and the cultures where the plankton grew decreased slowly during the stationary phase.

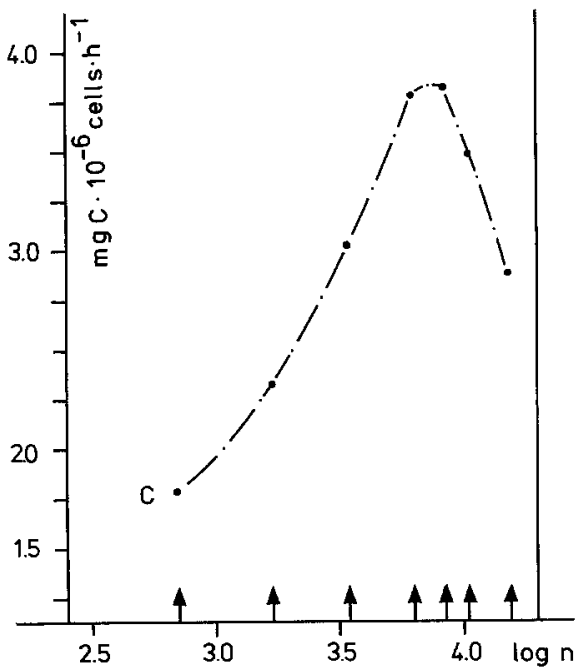

Fig. 1. Coscinodiscus granii. Variations observed in the carbon fixation rate of the control containing only $0.1 \mu \mathrm{g} \mathrm{Cd}^{-1}$ as a function of the cell density. Values are plotted as the geometric means of data obtained on two successive days. Sampling is indicated by arrows (each sample taken after $24 \mathrm{~h}$ )

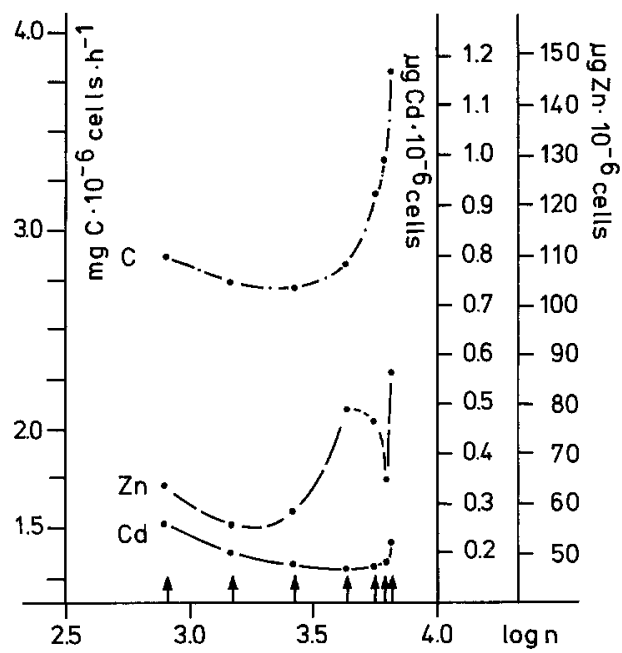

Fig. 2. Coscinodiscus granii. Variations observed on the carbon fixation rate and the cadmium and zinc levels in the cells as a function of the cell densities in the culture containing $1.5 \mu \mathrm{g} \mathrm{Cd} \mathrm{l}^{-1}$. Values are plotted as the geometric means of data obtained on two successive days. Sampling is indicated by arrows (each sample taken after $24 \mathrm{~h}$ ) 
The uptake of zinc illustrated the different responses of cells to metals during the various phases of the culture growth (Figs 2-4). During the exponential growth phase, the zinc level of the plankton decreased and usually went up again during the stationary phase. Cells in bad physiological condition contained very high levels of $\mathrm{Zn}$. The highly

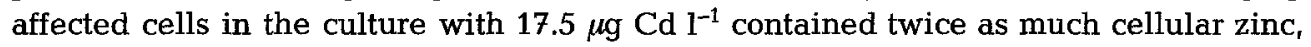
and those with $26.5 \mathrm{mg} \mathrm{Cd} \mathrm{I}^{-1} 3$ to 4 times as much zinc as the other samples.

In general, the mean concentration factors were very low (Table 1); up to $17.5 \mu \mathrm{g} \mathrm{Cd}$ $\mathrm{l}^{-1}$, they varied between 41 and 73 for cadmium and 850 and 1183 for zinc calculated on a wet weight basis. The culture containing $26.5 \mu \mathrm{g} \mathrm{Cd}^{-1}$ had slightly higher concentration factors, 103 for cadmium and 1903 for zinc.

A significant difference at the $95 \%$ level using a $t$-test (16 degrees freedom) was found between living and dead cells, dead cells containing 3.2 times more Cd and 4.0 times more $\mathrm{Zn}$ than living ones. Additional short-term experiments over $25 \mathrm{~h}$ where the metal uptake of living cells and of cells killed by heating to $50{ }^{\circ} \mathrm{C}$ was measured confirmed this, but a dependence on the cadmium concentration of the solution was observed, lower concentration factors occurring at higher Cd levels in dead plankton.

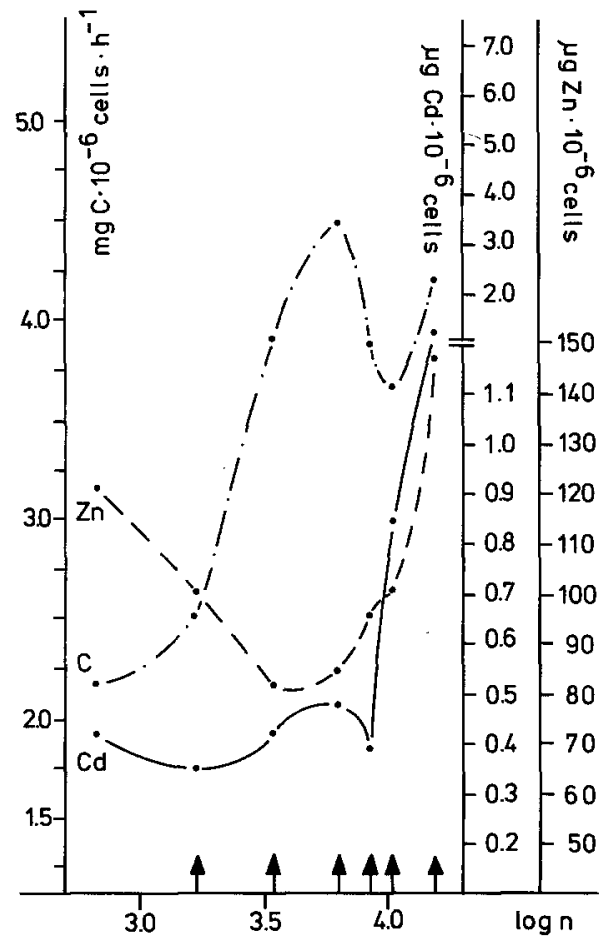

Fig. 3. Coscinodiscus granii. Variations observed in the carbon fixation rate and the cadmium and zinc levels in the cells as a function of the cell densities in the culture containing $4.0 \mu \mathrm{g}$ $\mathrm{Cd} \mathrm{1}^{-1}$. Values are plotted as the geometric means of data obtained on two successive days. Sampling is indicated by arrows (each sample taken after $24 \mathrm{~h}$ )

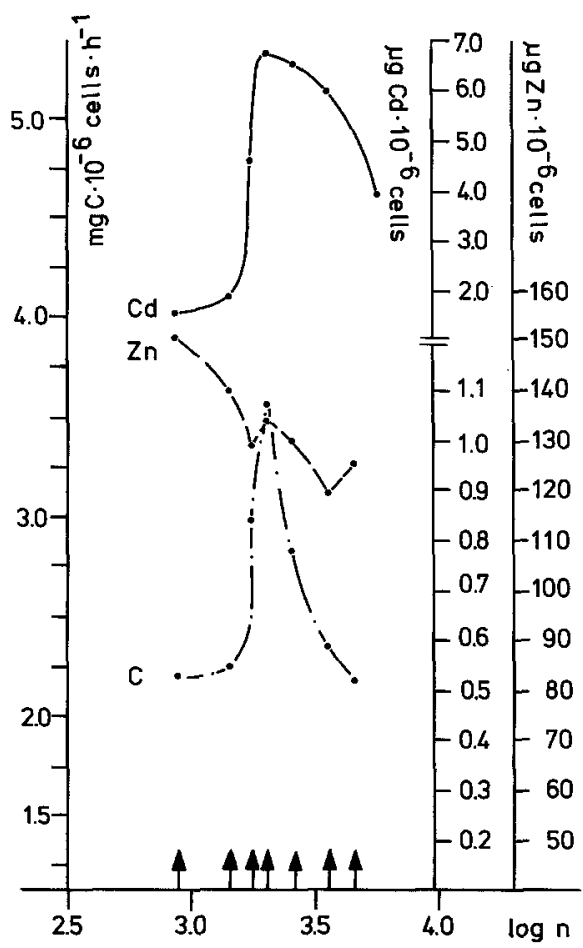

Fig. 4. Coscinodiscus granii. Variations observed in the carbon fixation rate and the cadmium and zinc levels in the cells as a function of the cell densities in the culture containing $17.5 \mu \mathrm{g}$ $\mathrm{Cd} \mathrm{l}^{-1}$. Values are plotted as the geometric means of data obtained on two successive days. Sampling is indicated by arrows (each sample taken after $24 \mathrm{~h}$ ) 
The carbon fixation rate varied between 1.75 and $4.5 \mathrm{mg}$ per $10^{6}$ cells and hour (Figs

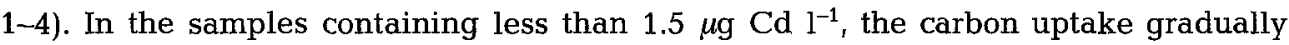
increased by up to a factor of 2 during the first 4 days, and then decreased. In the samples containing 1.5 to $9.1 \mu \mathrm{g} \mathrm{Cd} \mathrm{l}^{-1}$, however, the fixation rate either remained high during the stationary phase, or rapidly increased when cell growth was slowing down. At the highest cadmium concentration $\left(26.5 \mu \mathrm{g}^{-1}\right)$ the carbon fixation rate rapidly decreased after the first day due to the death of the cells.

As pointed out earlier, the standard deviation for counting the nuclides in clean water samples was within $\pm 2 \%$. Insufficient samples were taken to calculate the standard deviation for the measurements of the radioactivity on the filters, but filtered samples from healthy cultures showed a smaller variation than those from cultures containing high levels of cadmium or those in the last two days of the experiment. Because the numbers of plankton cells on the filters were known, it was expected that there would be good correlation between the radioactivity and the cell numbers on the filters. This was not the case; a possible explanation is the presence of the extruded cytoplasm which may have adsorbed additional $\mathrm{Cd}$ and $\mathrm{Zn}$.

To estimate the influence of bacteria on the uptake of metals and development of plankton, bacteria were counted every second day and the biomass calculated. Since the bacterial content of the stock cultures was fairly high, the bacteria sometimes represented a significant proportion of the total biomass after inoculation, in some samples being up to 8 to $13 \%$. This figure remained high only in slowly growing cultures and at the end of the experiment was normally around $1 \%$ (Table 1 ). In samples with partly dead plankton, the distribution of bacteria was not uniform because the dead cells were covered with many colonies. The metal content of the bacteria has not been allowed for in the calculations.

\section{DISCUSSION}

Schöne (1977) recently compiled data on the mean doubling time of Coscinodiscus granii and published data on his own experiments. The values reported in the experiments under discussion correspond very well with those reported in the literature for similar culture conditions. As mentioned already in the section "Materials and Methods", there exist at least two morphotypes of Coscinodiscus granii in addition to a variety aralensis (Ostenf.) Hust. It has to be taken into consideration that this variety and the two morphotypes might have different mean doubling times under comparable culture conditions. Schöne (1977) reported this phenomenon for the morphotypes of Coscinodiscus concinnus W. Smith. The behaviour in respect to heavy metals might also be different for the various morphotypes or in intraspecific taxa.

The confidence limits reported for the mean doubling time measured for the present experiments are fairly broad, compared with those reported by Schöne (1977) or others. The low cell density resulted in a relatively high variability in the cell counts in parallel subsamples. In addition, the cells might not have been distributed homogeneously before subsampling because the culture vessels, which were designed to avoid heavy metal contamination, could not be agitated sufficiently. The resulting range in the confidence limits for the mean doubling time, may have masked small changes in the growth rate of Coscinodiscus granii at low heavy metal concentrations. 
The uptake of cadmium and zinc depended mainly upon two factors: the age and general physiological condition of the cells, and the cadmium concentration. Often the uptake for cadmium was fairly high a short time after inoculation (Fig. 2). This may have been due to the fact that cells from cultures in the stationary phase usually had high cadmium binding capacities (Figs 2,3) and the stock cultures used for the experiment had just finished logarithmic growth.

The rapid uptake of cadmium by cells in cultures containing more than $8 \mu \mathrm{g} \mathrm{Cd} \mathrm{l}^{-1}$ was probably due to membrane disruption caused by the metal. The plasmolysis observed at $25 \mu \mathrm{g} \mathrm{Cd}^{-1}$ suggested that severe breakdown of the membrane occurred at this concentration. Cells which had accumulated high levels of cadmium while growing later lost some of the metal. Cossa (1976) found a similar effect.

Dead cells contained about 3 times more cadmium and about 4 times more zinc than living cells. The effect could lead to a partial detoxification of the metals in the culture medium. In the environment, it might also lead to a gradual sedimentation of toxic metals; even under natural conditions, there is a steady transport of trace metals to the sediment (Eaton, 1976; Kremling et al,, 1978). There are several possibilities to explain the enhanced metal content of dead cells. One reason might be that the frustules of the diatoms disrupted and offered twice the surface for accumulation than healthy cells. In addition the surface of the frustules may be used as substrate by bacteria which accumulate high levels of heavy metals. There is also some evidence that cells in good physiological condition can actively prevent heavy-metal uptake.

The lowest cadmium concentration which significantly affected the growth rate was $17.5 \mu \mathrm{g}^{-1}$ but carbon fixation and cadmium uptake by the cells were both influenced by lower concentrations of the metal, especially in the range of 1.5 to $9.0 \mu \mathrm{g} \mathrm{Cd} \mathrm{l}^{-1}$. These levels are considerably lower than those which have been previously found to affect diatoms. Overnell (1976), for example, observed no effect up to $112.4 \mathrm{mg} \mathrm{Cd}^{-1}$ with Phaeodactylum tricornutum and Skeletonema costatum. However, Overnell's medium contained $0.01 \mathrm{M}$ concentrations of $\mathrm{pH}$ buffers which may have formed chelates with the added metals. Furthermore, the high chlorophyll levels in his experiments suggest that dense cultures were used; these would require higher cadmium levels to reach the cellular burdens necessary to produce physiological effects. Bentley-Mowat \& Reid (1977) found in a medium containing $1.3 \times 10^{-4} \mathrm{M}$ EDTA that Phaeodactylum tricornu-

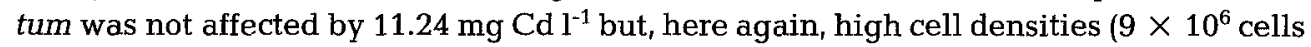
$\mathrm{ml}^{-1}$ ) were employed.

Kayser reported that zinc concentrations as low as $50 \mu \mathrm{g} \mathrm{l} \mathrm{l}^{-1}$ reduced the growth of the diatom Schroederella schroederi. The present culture medium contained $38 \mu \mathrm{g} \mathrm{Zn}^{-1}$ so that the observed effects may, in fact, have been due to a synergistic effect between zinc and cadmium similar to that reported for copper and zinc in Amphidinium carterae cultures (Braek et al., 1976).

Acknowledgements. We thank the Deutsche Forschungsgemeinschaft for financial support. Dr. $H$. J. Krambeck (Plön) calculated the mean doubling time. We are also grateful to Dr. A. G. Davies (Plymouth) for helpful discussions and correcting the manuscript. 
Barber, R. T., Dugdale, R. C., MacIsaac, J. J. \& Smith, R. L., 1971. Variations in phytoplankton growth associated with the source and conditioning of upwelling water. - Investigación pesq. $35,171-193$.

Barber, R. T. \& Ryther, H. J., 1969. Organic chelators affecting primary production in the Cromwell Current upwelling. - J. exp. mar. Biol. Ecol. 3, 191-199.

Bentley-Mowat, J. A. \& Reid, S. M., 1977. Survival of marine phytoplankton in high concentrations of heavy metals, and uptake of copper. - J. exp. mar. Biol. Ecol, 26, 249-264.

Braek, G. S., Jensen, A. \& Mohus, Å., 1976. Heavy metal tolerance of marine phytoplankton. III. Combined effects of copper and zinc ions on cultures of four common species. - J. exp. mar. Biol. Ecol. 25, 37-50.

Cossa, D., 1976. Sorption du cadmium par une population de la diatomée Phaeodactilum tricornutum en culture. - Mar. Biol. 34, 163-167.

Davies, A. G., 1978. Pollution studies with marine plankton. Part. II. Heavy metals. - Adv. mar. Biol. $15,381-508$.

Dawson, R. \& Liebezeit, G., 1980. Analytical methods for characterisation of organics in sea water. In: Organic chemistry of sea water. Ed. by E. K. Duursma \& R. Dawson. Elsevier, Amsterdam (in press).

Drebes, G., 1974. Marines Phytoplankton. Thieme, Stuttgart, $186 \mathrm{pp}$.

Eaton, A., 1976. Marine geochemistry of cadmium. - Mar. Chem. 4, 141-154.

Hellebust, J. A., 1974. Extracellular products. In: Algal physiology and biochemistry. Ed. by W. D. P. Stewart. Blackwell, Oxford, 838-863.

Kayser, H., 1977. Effect of zinc sulphate on the growth of mono- and multispecies cultures of some marine plankton algae. - Helgoländer wiss. Meeresunters. 30, 682-696.

Kremling, K., Piuze, J., Bröckel, K. von \& Wong, C. S., 1978. Studies on the pathways and effects of cadmium in controlled ecosystem enclosures. - Mar. Biol. 48, 1-10.

McLachlan, J., 1973. Growth media - marine. In: Handbook of phycological methods. Ed. by J. R. Stein. Cambridge Univ. Press, London, 25-51.

Overnell, J., 1976. Inhibition of marine algal photosynthesis by heavy metals. - Mar. Biol. 38, $335-342$.

Riley, J. P. \& Taylor, D., 1972. The concentration of cadmium, copper, iron, manganese, molybdenum, nickel, vanadium, and zinc in part of the tropical north-east Atlantic Ocean. - Deep Sea Res. 19, 303-317.

Schöne, H. K., 1977. Die Vermehrungsrate mariner Planktondiatomeen als Parameter in der Ökosystemanalyse. Habil.Schr., RWTH, Aachen, 1-323.

Spencer, C. P., 1958. The chemistry of ethylenediamine tetra-acetic acid in the sea water. - J. mar. biol. Ass. U. K. 37, 127-144.

Steemann-Nielsen,'E. \& Wium-Anderson, S., 1971. The influence of $\mathrm{Cu}$ on photosynthesis and growth in diatoms. - Physiologia Pl. 24, 480-484. 